surer. It too depends on the compression of air, but in it the extent to which the air has been compressed is marked directly on the interior of a straight glass tube by the chemical action of sea-water on a preparation of chromate of silver with which the tube is lined internally. Between the salt of the sea-water and the chromate of silver a double decomposition takes place. The chlorine leaves the sodium of the common salt and combines with the silver, while the chromic acid and oxygen leave the silver and combine with the sodium. Thus chloride of silver, white and insoluble, remains on the glass in place of the orangecoloured chromate of silver lining as far up as the water has been forced into the tube, and the chromate of sodium dissolved in the water is expelled as the air expands when the tube is brought to the surface.

My mavigational spunding machine was brought into practical use for the first time in the steamship Palm, belonging to Messrs. Charles Horsfall and Co., Liverpool, in a voyage to Odessa and back about a year ago, in command of Capt. E. Leighton. I cannot illustrate the use of the machine better than by reading to you an extract from a letter I received last April from Capt. Leighton, describing his experience of it in this first trial :-

"During the voyage in the Palm steamship, which has just come to an end, I took frequent opportunities of testing the sounding machine when I had a chance of cross-bearings to verify the depths as shown by chart, and always found it most accurate. For instance, going up through the Archipelago and just after clearing the Zea Channel, I got a good position by bearings, chart showing seventy-nine and seventy-six fathoms, two casts of your glass gave seventy-eight and seventy-five fathoms. In the Bosphorus also it gave capital results in thirty to forty fathons water.

" "The first real use I made of the machine was in the Black Sea during a fog which obscured everything. Wishing to make sure of my position I put the ship's head for the land and kept the machine at work. After running in to thirty fathoms at full speed I slowed down and went in to twelve fathoms, then hauled, out to a convenient depth and put her on the course up the coast. When it became clear I found myself in a proper position, and no time had been lost by stopping to sound.

" How many shipmasters let hours go by without obtaining soundings either because of the delay or on account of the danger of rounding-to in heavy. weather to get them, when, if they were provided with your sounding-machine, they could have their minds set at ease by having timely warning of danger, or by knowing that they were in a good position!"

I had myself very satisfactory experience of the usefulness of the sounding machine in coming up Channel running before a gale of south-west wind in thick weather, on the 6th and 7 th of last August, on returning from Nacieira in my yacht-a small sailing schooner of 126 tons. About 5 A.M. on the 6th I took two casts and found ninety-eight fathoms (sand and red spots) and $10 \mathrm{I}$ fathoms (sand and small shells). The mean with a correction of $2 \frac{1}{2}$ fathoms to reduce to low water, according to the state of the tide at Usbant at the time, was ninety-seven fathoms. Thenceforward I took a sounding every hour but one till eight in the evening. By writing these soundings on the edge of a piece of paper at distances equal according to the scale of the chart to the distances run in the intervals, with the edge of the paper always parallel to the course, according to the method of Sir James Anderson and Capt. Moriarty, $X$ had fixed accurately the line along which the vessel had sailed, and the point of it which had been reached, with only a verification by a noon latitude. At 6 o'clock next morning, by the soundings and course, with proper allowance for the flood-tide, I must have been about thirteen miles magnetic south of the Start, but nothing of the land was to be seen through the haze and rain; and with the assistance of about ten more casts of the lead (by which I was saved from passing south of St. Catherine's) I made the Needles Lighthouse right ahtad, at a distance of about three miles, at 2 P.M., having had just a glimpse of the high cliffs east of Portland, but no other sight of land since leaving Madeira and Porto Santo. In the course of the 280 miles from the point where I struck the roo fathom line to the Needles, I took about thirty casts in depths of roo fathoms to nineteen fathoms without once rounding-to or reducing speed; during some of the casts the speed was ten knots, and the average rate of the last 220 miles was a little over nine knots.

It is a pleasure to me to be able to add that the sounding machine has also been successfully used in the Royal Navy,
Admiral Beauchamp Seymour and Capt. Lord Walter Kerr having kindly taken it on board H.M.S. Mino'aur for trial last summer. Lord Walter Kerr wrote, on his return from Vigo, regarding it as follows :-

"The sounding machine is most serviceable. We have been using it constantly when running up Channel, from the time of crossing the line of soundings to the time of reaching Plymouth, and though running before a gale of wind with a heavy sea, at the rate of ten knots, we were able to get soundings as if the ship had been at anchor. We were able to signal to the squadron each sounding as it was obtained; thus, in thick weather, verifying our position by soundings without having to round the ships to."

\section{THE ANALOGIES OF PLANT AND ANIMAL LIFE} ET us begin our inquiry into the analogies of plant and
animal life by comparing the egg of an animal with the seed of a plant. Let it be the ripe seed of a common plant, and the egg of a bird. Both seed and egg may be said to consist of the young creature and a supply of food which is stored up for its use, and is gradually exhausted as the young creature develops. Every one who has tried when a boy to blow a late bird's egg must have been painfully alive to the fact of its containing a young animal, and the egg we eat for breakfast may serve to remind us of the store of food which we diverted from its proper course of nourishing a young chicken.

Here is a diagram representing a section through the seed of a poppy, in which the young plant may be seen lying in its store of food containing a supply of carbohydrates and nitrogenous matter, which is consumed as the yolk of the egg is consumed by the young chicken. Other seeds, such as a bean, an acorn, or ar almond, seem at first sight to consist of nothing but the young plant, and to have no store of food. The two halves into which a pea split are the two first leaves or cotyledons of the yourig plant, the emoryo stem and root being represented by the little projecting mass lying between the two halves at one end of the seed. Here the store of food is laid up in the body of the young plant just as many young animals carry with them a store of food in the shape of the masses of fat with which they are cushioned; the two leaves which seem so gigantic compared with the rest of the plant are filled with nutriment, and perform the same function of supplying food for the growth of the seedling, which is performed by the mass of nutrient material in which the entbryo of the poppy seed is embedded. Recent researches have shown that embryo plants are possessed of powers which even in the present day it seems almost ludicrous to ascribe to them. I mean powers of digestion. GorupBesanez, 2 a distinmuished German chemist, found that in the germinating seed of a vetch a ferment exists similar to the ferment in the pancreatic secretion of animals-a secretion having the power of relucing both nitrogenous bodies and starch to a condition in which they can be utilised and absorbed by the tissues, so that the embryo plant behaves exactly as if it were a minute animal digesting and absorbing the store of food with which it is supplied. The power of digesting starch possessed by the embryo plant has been brilliantly demonstrated by van Tieghem, ${ }^{3}$ who found that the embryo removed from the sced of the Marvel of Peru (Mirabilis jalapa) was distinctly nourished if placed in an artificial seed made of starch paste. He found that the starch paste was actually corroded by the young plant, proving that a digestive ferment had been at work.

This wonderful experiment is of special interest as proving that the digestive ferment is a product of the young plant itself, just as the digestive juice of an animal is a secretion from its stomach. It is indeed a striking thought that whether we grind up a grain of wheat to flour and eat it ourselves as bread, or whether we let the seed germinate, in which case the young plant eats it, the process is identically the same.

The power of storing up food in a fixed condition and utilising it when required is a most imporfant function both in animal and plant physiology. And just as this utilisation is seen in the seed to be brought about by a fermentby a digestive process--so probably wherever the transference or utilisation of food stores occurs it is effected by ferments. If this be so it would seem that the processes of

${ }^{x}$ A Lecture delivered at the London Institution on March $x$ by Francis Darwin, M.B.

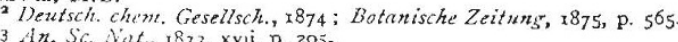
3 An. Sc. Natt., 1873 , xvi. p. 205 . 
digestion proper, as they occur in the stomach and intestines of animals and on the leaves of carnivorous plants, I say it is probable that these processes are only a specialisation ${ }^{1}$ of a widely spread power, which may exist in the simplest protoplasmic ancestor of animals and plants. In this case twe shall have no right to consider the existence of carnivorous plants anything strange or bizarre; we should not consider ir, as seems sometimes to be done, an eccentric and unaccountable assumption of animal properties by plants ; but rather the appearance of a function which we have quite as much right to expect in plants as in animals. Not that this view makes the fact of vegetable digestion any less wonderful, but rather more interesting as probably binding together by community of descent a wide class of physiological functions. Let us now pass on to consider the analogies of plants and animals in a more advanced stage of life.

Great differences exist among animals as to the degree of development attained before the young ones enter the world. A young kangaroo is born in a comparatively early stage of development, aud is merely capable of passive existence in its mother's pouch, while a young calf or lamb soon leads an active existence. Or compare a human child which passes through so prolonged. a condition of helplessness, with a young chicken which runs about and picks up grain directly it is out of its shell. As analogous cases among plants, we may take the mangrove and the tobacco plant. The ripe seed of the mangrove is not scattered abroad, but remains attached to the capsule still hanging on the mother plant. In this state the seeds germinate and the roots grow out and down to the sea-level, and the plant is not deserted by its mother until it has got well established in the mud. It is due to the young mangrove to say that the con. ditions of life against which it has to make a start are very hard on it. The most intrepid seedling might well cling to its parent on finding that it was expected to germinate on soft mud daily fluoded by the tide. Perhaps the same excuse may be offered for the helplessness of babies-the more complicated the conditions of life, the greater dependence must there be of offspring on varent.

Now compare a young tobacco plant with the mangrove. All the help the seedling tobacco receives from its parent is a very small supply of fuod; this it uses up in forming its first pair of leaves; it has then nothing left by way of reserve, but must depend on its own exertious for subsistence. by its own exertions I mean its power of manufacturing starch (which is the great article of food required by plants) from the carbonic acid in the air. In this respect it is like a caterpillar which is formed from the contents of the egg, but has to get its cwn living as soon as it is born.

In many cases there is a certain degree of independence in young creatures, which are nevertheless largely dependent on their parents' help. Thus, young chickens, though able to feed themselves, depend on their mother for warmth and guidance. A somewhat parallel case may be found among plants. has been shown that the large store of reserve material in a bean is not all needed for the development of the seedling. It has been proved that well-formed and llourishing seedlings are produced, even when a large part of the cotyledons has been removed. In tact, the store of food in the bean has been said to play a double part in the economy of the plant, ${ }^{2}$ first, as giving absolutely necessary formative material, and secondly, as protecting the young plant in the struggle with other plants, by supplying it with food till it is well established and able to make its own food. This view was fully established by my father, ${ }^{3}$ who sowed various kinds of seed among grass in oraer to observe the struggle; he found that peas and beans were able to make a vigoruus start in growth, while many. other young plants were killed off as soon as they germinated.

The young bean is thus indirectly protected by its mother from death, which the severe competition entails on less fortunate seedlings. This kind of protection can only in a certain general sense be compared with the protection given by parent to offspring. Nevertheless, a more strictly parallel case may be found among animals. : Certain fishes retain the yolk bag, still containing a supply of food, and swim about leading an independent life, carrying this store with them. Among plants, a good case of a retention of a store of food occurs ${ }^{4}$ in the oak. Young trees

I See Morren, "La Digestion Végétale," Gand, r876; and Pfeffer, "Landwirth. Jahrb.," 1877 .

a Haberlandt, "Schutzeinichtungen in der Entwickelungen der Keimpflanzen," 1877, p 29. The idea is quoted as originally given by Sachs,

3 See "Urigin of Species," 6th edition, p. 60.

4 See Origin of Specindt, possessing woody stems and several leaves may still have an acorn underground with an unexhausted store of food.

In comparing the lives of plants and animals, one is struck with the different relation which the welfare of the race bears to the welfare of the individual. In plants it is far more obvious that the aim and object of existence is the perpetuation of the species. The striking and varied development of the reproductive organs in plantsis one tactor in this difference. Roughly speaking, plantsstrike us most by their flowers and seed-that is by organs serving the interest of the race. Animals are most striking on account of their movements, which are chiefly connected with the wants of the individual. If a child wants to know whecher a stick is a stick or a citerpillar, he touches it, and if it walks off, classes it in the animal kingdom. Of course, I do not mean that the power of movement is a mark of distinction between animals and plants, but it certainly is a power which is well developed in most animals, and badly developed in most plants. It is the absence of locomotive powers (as opposed to the absence of simple movements) that especially characterises most plants. One sees the meaning of this if one inquires into mode of life of stationary and of locomotive animals. Stationary animals either inhabit the water, or else are parasitic in habits, and live on tissues of plants or animals. In either case the absence of locomotion has the same meaning. Many aquatic animals derive their food from the minute organic particles floating in the water, so that even though they lead a stationary life, food will be brought to them by the currents in the water. Parasitic animals obtain their food directly from the juices or sap of their host, so that they do not need to move about as other animals do in search of food. In the same way plants live like parasites on the earth, penetrating it with their roots, and sucking out its juices; and their fuod-carbonic acid-is brought to them by the currents of the air, so that like both an aquatic and a parasitic animal, they have no need of locomotion as far as concerns the obtaining of fund.

In the case of many young animals their powers of locomo. tion wrould he uselejs uriless the egrs were deposited by the mother in a proper piace; one cannot imagiue any:hing wore forloru than a caterpillar reared from an egg laid anywhere by chance, and expected to find its proper plant. The necessity of finding proper places to lay her eggs implies the necessity of locomotion on the part of the motner. This need of locomotion is, of course, equally a need to the plant, but it is supplied in a distributed way. The seeds themselves become locomotive; they either acquire plumes to fly on the wind like the seeds of dandelions or they become burrs and ciing to passing animals, or are distributed in otber ways. Various and strange are the means of transportal adopted by seeds; for instance, the acorn seems to distribute itself by deliberately trading on the carelessness of creatures which are usualiy considered its superiors in intelligence. Good evidence exists that young oaks which grow scattered in large number over a wide extent of wild heathy land have spiung from the acorns accidentally dropped by passing rooks. In all these cases the young plant has to trust to chance as to what kind of soil it will be deposited in, and this of course accounts for the enormous number of seeds produced by plants. Sume seeds are more fortunate in possessing a kind of mechanical choice or power of selecting suitable places to grow in. Many years ago my father described a plumed seed which, when damped, poured out a sticky substance capable of gluing the seed firmly to whatever touched it. Imagine such a plant blown by the wind over some sandy waste; nothing tends to stay its course till it happens to pass by a region where the soil is damper; then it sends out its sticky anchors, and thus comes to rest just where it has a chance of germinating favourably. Again, some seeds have a certain amount of locomotive power independent of such externat agencies as wind or passing animals. I mean a power of burying themselves in the ground; the seeds of igrasses are the best known of these selt-burying seeds; ard annong them the feather-grass, or Stipa pennata; is the most conspicuous These seeds possess a strong, sharp point, armed with a plume or tuft of recurved hairs, which act like the barbs of an arrow and prevent the seed from coming out again when it has once penetrated the soil. This arrow-like point is fixed at the lower end of a strong awn, which has the remarkable property of twisting when dried and intwisting when wetted.' Thus the mere alternations of damp rights arid dry days cause the arrowlike point to rotate, and by another contrivance; which it would take too long to go into, the point 'is pressed against the surface of the ground and actualiy bores its way into it. Fritz Müller 
described in a letter to me how these twisting grass seeds bury themselves in the extremely hard and dry soil of Brazil, and are thus no doubt enabled to germinate. Unfortunately these boring grass-seeds do not always confine themselves to penetrating the soil, but exercise their powers on both men and animals. I have received accounts from India and from Italy of the way in which the sharp-pointed seeds work their way through thick trousers into the legs of unfortunate sportsmen. But the most extraordinary case is that of certain grasses which work their way into sheep. They often penetrate the skin deeply and in large numbers, inflicting great to tures and often causing death by emaciation. Mr. Hinde, of Toronto, has given me the details of this plague to sheep-farmers as it occurs in Buenos Ayres. Another observer has described it in Australia. ${ }^{1}$ He states that not unfrequently the seeds are found actually piercing the heart, liver, and kidneys of sheep which have died from the effects. I believe that the northern part of Queensland has been actually given up as a sheep country because of the presence of this grass.

Another use to which locomotion is applied by animals is that of finding a mate at the proper season. The curious imitation of the courtship of antmals which is found in Vallismeria is well known. The stalk grows with extreme rapidity up through the water till the female flower reaches the surface, and there awaits the approach of the male flower, which breaks loose and fluats down the stream to meet her. But most plants have not even this amount of locomotive power, and are therefore compelled to employ either the wind or insects as go-betweens. Fortunately for the beauty and sweetness of our woods and fields, insect fertilisation is the commonest means adopted; and all the bright flowers and sweet smells of flowers are nothing but ailurements held out to insects to entice them to carry the fertilising pollen from one flower to another. It is curious to find a plant adopting a new mode of conveying its pollen when the old one fails. Thus, a wild cabbage-like plant which grows in Kerguelen's Land is now fertilised ty the wind, that is, it produces dry clust-like polien, which is casily carried by the wiud. Now this cabbage is the only species in the enormous order of the Crucifor $x$ wlich is not fertilised by insects; so that we may be certain that a change has taken place for which some sufficient reason must exist. And the reason of the change is no doubt that the insects in Kerguelen's Land are wingless, and are therefore bad distributors of pollen. And to go one step further back, the reason why the insects are wingless is to be found in the prevalent high winds. Those insects which attempt to fly get blown out to sea, and only those are preserved which are gradually giving up the habit of flying. Thus the pollen of the cabhage has to learn to ny, because the insects will not fly for it.

In considering the analogies between plants and animals, one cannot merely compare those functions which are strictly and physiologically similar in the two kingdoms. One rather sets to work and studies the needis which arise in either a plant or an animal, and then discovers in what way the same need is supplied in the other kingdom. There is no connection between a plant having bright fowers and an animal's power of walking about, yet they may, as we have seen, play the same part in the economy of the two lives.

In the life of animals the first needs that arise are supplied by certain instinctive movements. The young chicken only escapes from its egg by some such movements. Mr. W. Marshall has also shown that the chrysalides of certain moths possess instinctive movements by which they escape from the cocoon or outer case. In one case a sharp spike is developed, sticking out from the side of the chrysalis, and as the latter rotates the spike saws the cocoon all round, so that the top lifts off like a lid. Again, in young chickens Spalding has shown the existence of an instinctive power of obtaining food, and instinctive recognition of the hen by sound only. This was proved by a newly-hatched chicken, which had never heard or seen its mother, running towards a cask under which a clucking hen was hidden. The powers of growth which exist in young seedlings would certainly be called instinctive if they existed in animals, and they are quite as indispensable as those just mentioned in supplying the wants which first arise.

These two instincts are the power of directing the growth in relation to the force of gravity, and in relation to light; the first being called geotropism, the second heliotropism. As soon as the young root emerges fron the seed-coats, it turns abruptly downwards, perceiving like the chick in what direction the earth, its mother, lies. Thus the young plant fixes itself firmly in the I. C. Prentice, Foumul of Botany, 1872, p. 22. ground as quickly as possible, and is enabled to begin to make arrangements for its water supply. At the same time the young stem grows upwards, and thus raises itself as much as possible over its neigbbours. The power of directing itself vertically upwards is also a necessity to the plant, because without it no massive growth like that of a tree would be possible. It would be like a child trying to build a wooden house with bricks that did not stand straight. Thus, both the young stem and the young root have an instinctive knowledge as to where the centre of the earth is-one growing towards the point, the other directly away from it. This fact is so familiar to us, that we fail to think of it as wonderful; it seems a matter of course, like a stone falling or a cork floating on water. Yet we cannot even generalise the fact so far as to say it is the nature of all stems to grow up, and all roots to grow down, for some stems, such as the runner of a strawberry, have a strong wish to grow down instead of up, and side roots that spring from the main ones, though their method of growth is identical with that of the main roots, have no wish to grow downwards. We can find no structural reason at all why a root should grow down and a stem up. But we can see that if a plant took to burying its leaves and rearing its roots into the air, it would have a bad chance in the struggle for life. It is, in fact, the needs of existence which have imipressed these modes of growth on the different organs of the plant in accordance $\mathrm{sith}$ their various requirements. On the other hand, the plant is not absolutely tied down by geotropism, it is not bound to grow alivicys in a vertical line, but is ready to be turned from its course if some other direction can be shown to be more advantageous. Thus Sachs ${ }^{1}$ planted peas in a litule sieve, and as the roots emerged underneath, they were enticed from the vertical by an oblique damp surface. This power of giving up the line of growth for the sake of a more advantageous prisition, must be of great service to roots, by enabling them to choose out damp places in the earth which a blind adherence to rule would have caused them to pass by.

The other tendency, which may be a'so compared to an instinct, is the power pussessed by the growing parts of plants of perceiving the position of the chief source of light. This tendency of course interieres with the geo:ropic tendency, for if the tip of a growing shoot bends towards the light it deviates from its vertical course. This contest between two instincts is well shown by placing a pot of seedlings close to a lamp or a window, in which case the heliotropic beats the geotropic tendency and the young plants curve strongly to the light ; now if the pot is removed to a dark room the geotropic tendency reasserts itself, and the seedlings become once more upright. One might fancy from this that the darkness of night would be always untioing any good gained by heliotropic growth in the day. An imagrinary case in the life of a seedling will show that it is not so. A seedling germinates under a pile of sticks : having few competitors it makes a good start, but in consequence of the clarkness it begins to starve as soon as it has exhausted the supply of food given it by its mother piant stored up in the seed from which it sprang. It starves because it is dark under the pile of sticks, and without light it cannot decompose the carbonic acid of the air and make starch; carbonic acid may be sard to be the raw material from which a plant makes its food-but without the help of light the plant is powerless to make foodit starves in the midst of plenty. So that the power of knowing where the light is and of moving towards it may be just as necessary to prevent a young plant starving as the power of knowing a grain of corn when it sees one and of snapping it up are to a young chicken. Luckily for our imaginary plant a ray of light streams in between two sticks-if the plant insisted on growing straight up in obedience to the geotropic instinct it would lose its chance of life. Fortunately the other light-seeking instinct wins the day and the plant thrusts its summit between the sticks and reaches the light. And now it is clear that when the plant has once got between the sticks the tendency to straighten again in the night will not be able to undo the advantage gained in the day by heliotropism. Besides the tendency to seek the light, there is in some plants another exactly opposite tendency to grow away from it. Just as in the case of geotropism no reason can be given why two organs should be affected in exactly an opposite manner by the same cause; no difference of structure can be perceived and no difference in manner of growth can be found between a tendril which grows away from the light and one which grows towards it. The convenience of the plant seems to dictate the result. Thus the virginian creeper climbs by forming little sticky feet at $x$ "Text Book of Botany," Eng. Tr. p. 764 . 
the end of its tendrils, and as it climbs up a support each new tendril is enabled by its power of seeking for darkness rather than light to find out little dark crannies in which to place its feet. On the other hand a bryony climbs by seizing anything it can get hold of, and as each tendril reaches out towards the light the whole plant will tend to be dragged towards the lighter side of the bush or hedge on which it clambers.

It looks as if the case might be put thus : Given the fact that light produces some kind of movement, the convenience of the plant shall decide whether it be towards the light or away from it; or in other words, grant the plant the power of knowing where the centre of the earth is, and grant it the power of knowing where the light comes from, then the plant itself can decide what course of growth is most advantageous. ${ }^{1}$

(To be continued.)

\section{NOTES}

THE subscription for M. Leverrier's statue is progressing favourably. A sum of 4,200 francs has been already collected. The "subscribers up to the present moment number thirty-five, almost all of them belonging to the French Institute. M. Cohen, of Antwerp, sent 1,000 francs. Other large sums are expected soon from different parts.

IT is stated that $M$. Faye has declined to stand for the direction of the Paris Observatory, unless it is agreed to retain at the observatory the International Meteorological Office. It is very probable that the long spoken of Meteorological Institute will now be established; at all events a solution of the pending question will soon be adopted by the government.

M. Dumas announced to the Paris Academy of Sciences at its sitting on March 4 that an anonymous donor offers a prize of 6,000 francs to be awarded in 1880 to the person who makes the most useful application of M. Pasteur's researches to the hea.ing art.

A COMMITTEE has been formed "at Königsberg to erect a fitting monument upon the grave of the great philosopher Im. maniel Kant. The City authorities have headed the list of subscriptions with the sum of 4,000 marks (200l.).

IN a report by M. Daubrée to the Paris Academy of Sciences it is strongly recommended that measures should be taken to preserve the many boulders which are scattered over France, and many of which are disappearing under the pick-axe of the builder. The Academy bas appointed a commission for the purpose, which will have delegates in the principal districts of the country. Similar measures have been taken in Switzerland since 1866 , and our Scotch geologists deserve praise for their zeal on behalf of the preservation of the boulders of their country, and for their excellent periodical reports on the subject.

Gen. Duff, in a letter to the Earl of Derby, dated Gothen. burg, January 4, reports that great shoals of herrings of the large kind which disappeared from this coast in the year I 809 have now made their appearance again north of Gothenburg. The first appearance of the herring took place at Christmas, when whales were seen following the shoals toward the coast. Preparations were male by the merchants of Gothenburg to make good use of this godsend. It would appear from the history and traditions of Sweden that, after an interval of seventy years, there are some grounds for supposing that the shoals of herrings may be expected to visit the coast regularly for fifty or sixty years to come, as has been the case during earlier periods. The $\mathrm{S}$ wedish Guvernment have appointed Professors Sars and Srritt to inquire into the various questions raised by this sudoen appearance of the herring shuals off this part of the Swedish coast, the more important of these questions being the

I I have spoken as if the existence of positive and negative belio-and geotropism could be simply explained by considering the convenience of the geotropism could be sinply explained by con heliotropic, (Sachs" "Text Book,".p. 755.) alleged disappearance of the shoals from the caast of Norway, whither, it is said, they have betaken themselves since 1808 , and the bearing of the inquiry on the future of the fishery.

THE first National Entomological Exhibition commenced on Thursday at the Royal Aquarium, Westminster, and is thoroughly creditable to all concerned. There are altogether about 250 exhibitors contributing between eight and nine hundred cases, with an average of at least 300 insects per case; and the whole of the specimens shown, with very few exceptions, have been collected by ladies and gentlemen and artisans, in theip leisure hours.

WE regret to learn the death of Joachim Monteiro, at Delagoa Bay. He was an active and enterprising naturalist, whose work on Angola will give him an enduring place in the literature of African travel, no Jess than his services in procuring and sending to this country a great part of the fine series of specimens from which Welwilschia was originally described.

THE death is announced of Sulhiz Kurz, the Curator of the Herbarium of the Calcutta Botanic Garden. Possessed of an extensive knowledge of Indian botany, he had recently com. pleted the preparation of a Flora of Briti.h Burma for the Indian Forest Department. He died at Penang on his way to the islands of the Malayan Archipelago, for the purpose of botanical exploration.

A LETTER has been written by the Municipal Council of Paris to the director of the Meteorological Service of the Observatory asking that the publication of weather telegrams and prognosti. cations he made in Paris as well as in provincial towns.

A GREAT prehistoric burial ground has recently been disa covered at Cremmen (in the district of East-Havelland, Prussia), nct far from Berlin. Numerous urns and ash.jars of varied form, all containing ashes and bones of burnt buman xemains, have been found, The urns are mostly round in shape, and stood some $2 \frac{1}{2}$ to 3 feet below the suriace upon a large slab of stone; they were surrounded by round stones, and each was covered with a flat stone lid. The antiquities will all bo deposited in the Provincial Museum of Berlin.

AN International Agricultural Exhibition will take place at Hamburg on June 13 , and will last 5 days; and another exhibition of this nature will be held at Prague on May 15,16 , and 17 .

The Royal Society for Agriculture and Botany of Ghent, will hold its Horticultural International Exhibition on March $3 \mathrm{I}$ next. These exhibitions are quinquennial, and last for seven days. The coming one promises to be unusually brilliant, to judge from the copious list of names of exhibitors.

We are glad to see that a beginning has been made in the formation of a local museum at Tenby, the proposal for which we referred to some time since. The magnificent geological collection of the late Mr. Smith, of Gumfreston, has been pur. chased. The Corporation of Tenby has given the old Natival School-rooms on the Castle Hill, and after some slight altera. tions have been made they will be admirably well adapted for a museum. In addition to the geological specimens there will be a valuable collection of British shells, and one of Pembroleshire birds and eggs ; also a library of scientific books. It would be idle to speak of the advantage this institution is likely 10 confer on the town, and on all the residents in South-west Wales, where notbing worthy of the name of a museum at preient exists. About $300 l$. is still required bsfore the museum can be opene:? The trustees ought to have no difficulty in raising this moderate sum in the district concerned; perhaps some of our readers might like to contribute, The hon. secretary is Mr. Idward Laws, Tenby. 